\title{
Toward a Professional Responsibility Theory of Public Relations Ethics
}

\author{
Kathy Fitzpatrick \\ University of Florida \\ Candace Gauthier \\ University of North Carolina
}

\begin{abstract}
$\square$ This article contributes to the development of a professional responsibility theory of public relations ethics. Toward that end, we examine the roles of a public relations practitioner as a professional, an institutional advocate, and the public conscience of institutions served. In the article, we review previously suggested theories of public relations ethics and propose a new theory based on the public relations professional's dual obligations to serve client organizations and the public interest.
\end{abstract}

The leading association in the public relations industry defines the purpose of public relations as follows: "Public Relations helps our complex, pluralistic society to reach decisions and function more effectively by contributing to mutual understanding among groups and institutions. It serves to bring private and public policies into harmony" (Public Relations Society of America Foundations, 1991, p. 4). The same association describes the work of the public relations professional: "The public relations practitioner acts as a counselor to management and as a mediator, helping translate private aims into reasonable, publicly acceptable policy and action (Public Relations Society of America Foundations, 1991, p. 4).

These rather vague statements are among hundreds that have been offered to explain the term and function of those working in public relations. Many who have studied or practiced public relations have pondered-but seldom agreed - on just what public relations is or exactly what those who do public relations should be or do. The result is that the field includes a lot of people doing a lot of things for a diverse group of institutions and interests.

Most professionals who provide public relations services offer counsel regarding the public implications of an institution's decisions and actions. They advise the institution on communication strategies and tactics that 
can be used to gain and maintain the support of important constituents, called publics or stakeholders. Techniques commonly used to help organizations establish positive relationships with the news media, employees, shareholders, communities, government officials, and other publics involve strategic, often persuasive, communication. In fact, to the embarrassment of many associated with the public relations field, the history of contemporary practices dates back to a time when manipulative publicity stunts frequently were used to influence people's attitudes toward an institution, its products, its services, its ideas, or all of these.

Some public relations scholars and practitioners believe that contemporary public relations has moved beyond persuasion and rhetoric as fundamental concepts, and that professional public relations work is driven by principles of negotiation and mediation as reflected in the preceding industry statement. The purpose of public relations, they say, is not to simply influence publics for the good of the institution. Rather, it is-or at least it should be-to help organizations and their publics accommodate each others' interests with a goal of mutual benefit (see, e.g., Grunig, 1992).

Others argue that persuasion remains at the heart of public relations work. "Despite a few voices to the contrary, public relations practitioners generally and readily accept persuasion and advocacy as their major function" (Kruckeberg \& Starck, 1988, p. 4). As such, the paramount interest served is that of the institution.

\section{Efforts include both self- interested .... and benevolent initiatives.}

In fact, both views are correct. Modern day public relations efforts include both self-interested persuasive tactics as well as genuinely benevolent initiatives. Still more involve mixed-motive communication programs and campaigns designed to benefit both institutions and their publics (see Murphy, 1991). In brief, the practice of public relations involves a multitude of communication strategies and tactics designed to influence the attitudes and behaviors of targeted audiences, generally for the good of the "sponsoring" organization and sometimes for the good of both the organization and others.

Throughout public relations' brief history, the partisan efforts of some practitioners have drawn criticism and raised questions concerning the ethical conduct of those who call themselves "public relations professionals." In some cases, criticism may be justified because of unprincipled practices. Just like guns, strategic communication can be used for 
legal and ethical purposes as well as for illegal and unethical purposes. Often, however, the criticism results from either a misunderstanding of or lack of appreciation for the function of public relations. The field has done a poor job in defining what public relations professionals do and in justifying their value and worth to society. The result is that public relations professionals continue to be plagued by charges of unethical conduct.

This state of the industry is the result of several factors. First, as noted earlier, the parameters for public relations work have not been-perhaps cannot be-clearly defined. Confusion regarding the role that public relations professionals should perform creates still more confusion regarding the ethical standards that should define public relations practices.

Second, public relations has not fully extricated itself from its journalistic roots. Many still believe that because public relations evolved from journalism - and is still taught primarily in schools and colleges of journalism and communication-public relations practitioners should share their journalistic counterpart's passion for objectivity. Of course, when measured by that yardstick, public relations professionals will never size up. Although advocates can be fair, they are seldom objective.

Third, there are no established minimal standards for the practice of public relations. States do not require practitioners to qualify for a license before hanging out a shingle. In the absence of such regulation, it is left to the industry itself to define standards of performance. Although industry associations have done a laudable job in developing codes of conduct for their members, the codes stop short of providing a theoretical basis for ethical decision making.

Finally, the values and ethics of the institutions represented by public relations professionals often are confused with the values and ethics of the individuals who provide counsel on such matters. When an institution is the subject of public criticism for perceived irresponsible behavior, the public relations representative shares the blame-regardless of his or her involvement in or knowledge of alleged bad acts. This "guilt by association" has become increasingly detrimental to the public relations industry as more and more organizations fail to meet public expectations.

Unfortunately, these problems are not easily resolved. Many have spent years trying to establish public relations as a legitimate and credible profession. A big step in achieving that goal will be the development of a universally accepted theory of public relation ethics. In that regard, much work remains to be done.

Although a number of theories of public relations ethics have been advanced, few have been fully developed. In fact, a review of public relations textbooks led one scholar to conclude that "there is no accepted conceptual framework from which to study public relations ethics" (Bivins, 1989, p. 
39). In a doctoral dissertation on public relations ethics, Pearson (1989x) concluded that "...many practitioners and scholars of public relations are capable of philosophical thought, but few seem to develop basic philosophical theory to under gird their discussion of public relations" (as cited in Grunig \& Grunig, 1996, p. 20).

So begins this study, which is a first step toward the development of a "professional responsibility theory" of public relations ethics. First, we briefly review existing theories of public relations ethics, pointing out weaknesses that limit each model's usefulness as a universal standard. We then consider the role of a public relations practitioner as a "professional," asking what special obligations attach to professional status and how such status does or should influence public relations practices.

Next, we explore the concepts of institutional advocate and "social conscience." Just what is a social conscience? Although the term frequently is used in reference to public relations practitioners, it has not been fully defined, nor seemingly widely accepted. Certainly the words suggest that public relations professionals have obligations that extend beyond a client organization's bottom line. Yet just what those obligations are and how they are realized is unclear.

We conclude the article with suggested principles that might serve as ethical guideposts for the responsible practice of public relations.

\section{Theoretical Bases for Public Relations Ethics}

\section{Attorney Adversary}

According to the attorney-adversary model, public relations performs the socially necessary role of professional advocacy within the adversary process essential to free enterprise and competition. It is argued that in the free market system, the public relations advocate functions the same way as does a lawyer who zealously represents his or her client in a court of law (Barney \& Black, 1994, p. 233).

Several questions raised by this model demonstrate its inadequacy as a standard for ethical public relations practice. In a court of law fairness is presumed. There is no such presumption in the media-driven court of public opinion. This court operates without specific rules of evidence and procedure that, in law, are designed to prevent undue prejudice against either side.

Judicial process rests on the assumption that, if both parties are adequately represented, the truth will emerge and justice will be served. Thus, when an attorney is appointed in criminal cases in which the defendant cannot afford one, the outcome is morally and legally questionable when a defendant is represented by incompetent counsel. In the court of public 
opinion, there is no guarantee that all interested parties will be represented or heard.

Defenders of this model have suggested that the public has a responsibility to gather and evaluate information that is relevant to their lives and choices (Barney \& Black, 1994, p. 241). Yet, when opposing voices are silent or important information is withheld, how will the public obtain information that challenges an institution's version of the truth? With access to only one version of the truth, how can the public take responsible action?

Finally, in a court of law the information that juries and judges receive and evaluate-the persuasion that they experience-and the truth that they discover through the adversary process will rarely have consequences for their own lives. On the other hand, the persuasive communication by public relations professionals potentially has far-reaching consequences for people's choices and actions.

\section{Enlightened Self-Interest}

According to the enlightened self-interest standard for persuasive communication, "... businesses do well (financially) by doing good (ethically), and it is, therefore, in their bottom-line interest to engage in good deeds and ethical behavior" (Baker, 1999, p. 73). This standard would allow corporate decisions and actions to be represented as in the public interest, even if their ultimate motivation is the financial benefit of the company.

In defense of enlightened self-interest, one commentator suggested that this form of justification is similar to utilitarian reasoning in which all of the options are weighed and the costs and benefits to all concerned parties are considered (Whalen, 1998, p. 6). However, there is an important methodological difference between the two. Enlightened self-interest clearly makes institutional benefits the priority and the ultimate motivation for decisions that benefit other groups or interests in society. After all, it is through these social benefits that an organization's benefits are attained. According to classical utilitarianism, however, an action's benefits and costs to all concerned parties are to be considered and weighed impartially (Mill, 1861/1979, pp. 16-17). Impartiality requires that the interests of those making the decision about an action are not to be valued any higher than the interests of others who will be affected by that action.

Critics of this model for public relations practice have pointed out several ethical problems. Representing corporate actions as based on "corporate social responsibility" implies that actions are done out of a sense of duty rather than from selfish motives (L'Etang, 1994, p. 117). From a Kantian perspective, such programs treat their beneficiaries as mere means to the end of corporate image and profits (L'Etang, 1994, p. 121). Moreover, representing the corporation's aims in terms of a duty or desire to benefit the community, 
rather than in terms of marketing strategy, may involve the public relations practitioner in blatant deception of the public (L'Etang, 1994, p. 121).

As David Martinson (1994) argued, ethical standards include considerations such as the welfare of others, the avoidance of injustice, respect for self and others, and the common good (pp. 104-105, 107). Based on these criteria, enlightened self-interest is not truly an ethical standard, as its focus is clearly on the self-interest of the company. Thus, this model will not be sufficient to guide the difficult ethical decisions that public relations professionals have to make (Martinson, 1994, p. 103).

\title{
Community/Communitarian/Social Responsibility
}

In comparison with enlightened self-interest, true social responsibility is taking actions and instituting policies that are morally right for that reason alone, without an ulterior self-interested motive. It is based on values such as honesty, respect, fairness, the avoidance of harm, and justice in the distribution of the benefits and burdens of living together in a democratic society. Social responsibility means first that one recognizes, accepts, and acts on a general responsibility to one's society. More specifically and more realistically it requires responsibility to those persons and interests who will be impacted by one's actions.

Baker (1999) proposed the "social responsibility model" as one possible baseline for professional persuasive communication. Such a model, she said

\begin{abstract}
Assumes that persons in society are interdependent communal beings; that corporate citizens have a responsibility to the societies in which they operate and from which they profit, including obligations of good citizenship in contributing positively to the social, political, environmental, and economic health of society; and the focus of one's actions and moral reasoning should be on responsibilities to others and to community rather than on one's individual rights. (Baker, 1999, p. 76)
\end{abstract}

It would be difficult to find a public relations professional who disagreed with the concepts espoused in ethical theories based on the need for enhanced social responsibility, good citizenship, and improved community relations. All of these concepts focus on the need for public relations to contribute to the betterment of both communities in which their clients and employers operate. Indeed, service to society is an important aspect of each model.

Kruckeberg and Starck (1980) went so far as to suggest that an ethical approach to public relations might be found through an emphasis on the restoration of community. Because many of the problems that public relations professionals concern themselves with in modern mass society stem di- 
rectly from the loss of community, they argued, "[a]n appropriate approach to practicing community (and public relations) must be derived through an active attempt to restore and maintain the sense of community that has been lost in contemporary society" (Kruckeberg \& Starck, 1988, p. 111).

Such thinking is reflective of the "communitarian" approach later suggested by Leeper (1996). Concluding that "the primary 'code of conduct' by which our behaviors are judged will focus on our social responsibilities to strengthen community and promote traditional American values including fairness, democracy, and truth" (p. 168), she somewhat hesitantly proposed that these "responsibilities and values, then, can be examined as a basis for a public relations ethical system" (p. 168).

Although laudable, theories of ethics based on the concept of social responsibility are particularly limiting in the effort to develop standards of practice in public relations because the primary focus is on the obligations of institutions rather than on the ethical obligations of public relations professionals. In addition, the lack of a clear definition of social responsibility confuses rather than clarifies what appropriate—ethical—counsel would require on the part of the public relations professional. Is participation in philanthropic endeavors enough to meet an institution's obligation to operate in the public interest? If not, what else is required? And is it public relations' role to decide such issues?

Another significant concern is that these approaches do little to resolve the inherent ambiguity in such phrases as "serve the public interest" or "serve society." As we discuss next, all professionals are deemed to serve the public interest. A significant question in the development of a theory of public relations ethics is how public relations professionals fulfill their social role. More specificity is needed to provide the public relations professional the intellectual tools needed for ethical reasoning.

\section{Sullivan's (1965) Partisan Values Versus Mutual Values}

The theory of public relations ethics set forth in 1965 by Albert Sullivan and later reviewed by Pearson (1989) rests on what Sullivan defined as the technical, partisan, and mutual values in public relations. According to Sullivan, "mutual values" that reflect respect for human rights should be viewed as "higher" than "partisan values" that can lead to too much commitment and too much obedience (Pearson, 1989, pp. 57). Because technical values are morally neutral, Pearson argued, the focus of public relations ethics lies at the point where partisan and mutual values intersect. Under this theory, partisan values rest on concepts of commitment, trust, loyalty, and obedience. Sullivan (1965) suggested that although a public relations practitioner's commitment to his or her client or employer is important, many take their partisanship to extremes, relying too heavily on the views 
of the organization while ignoring or minimizing the viewpoints of others (see Pearson, 1989).

Mutual values - or the "higher values," as Sullivan called them-are necessary to balance partisan values, because they "take into account the viewpoints, interests, and rights of others" (Pearson, 1989a, p. 57). Sullivan proposed a "principle of mutuality," which states "If one has a right, another...has an obligation to respect that right, to fulfill that right" (Pearson, 1989, p. 57). According to this theory, "because a person is rational, that person has a right to the preconditions for rationality," which involves access to accurate and complete information in matters that affect him or her (Pearson, 1989, p. 58). And because a person is free, "that person has a right to participate in decisions which affect him or her" (Pearson, 1989, p. 53). Pearson (1989) observed that "[p]erhaps Sullivan's most important contribution to ethical theory in public relations in his argument for institutional obligation to publics" (p. 57).

Certainly, as Pearson (1989) pointed out, Sullivan identified the thorniest ethical challenge for public relations professionals both then and now. Balancing the special interests of institutions represented with those affected by those institutions is the issue that seems to defy resolution. Also, Sullivan's rejection of zealous advocacy places him among many of today's commentators who call for increased attention to social responsibility on the part of both public relations professionals and the institutions they serve.

A significant question raised - but not answered—by Sullivan's theory is when it is appropriate, if ever, for public relations advocates to place the interests of others above the interests of institutions they represent. Pearson (1989a) noted that although Sullivan criticized public relations for excessive partisanship, he also said that it "would be the height of cynicism to advocate that practitioners should have no commitment to an employer" (p.56).

\section{Two-Way Symmetrical Model}

Another theory of public relations ethics that rests on principles of mutuality is that proposed by Grunig and Grunig (1996), who offered an ethical theory based on symmetric public relations. Under this approach, practitioners "play key roles in adjusting or adapting behaviors of [institutional] dominant coalitions, thus bringing publics and dominant coalitions closer together" (Grunig \& Grunig, 1996, p. 6). This "win-win" approach provides an ethical basis for public relations, they argued, because it "provides a coherent framework for socially responsible practices" (Grunig \& Grunig, 1996, p. 6).

Of course, it could be argued that in order for true symmetry to result, both sides must consider and weigh the effects of institutional decisions and actions and have the power to affect a particular outcome. In fact, 
Grunig and Grunig (1992) acknowledged that a symmetrical approach to public relations does not guarantee all parties equal benefit.

Symmetrical public relations provides a forum for dialogue, discussion, and discourse on issues for which people with different values generally come to different conclusions. As long as the dialogue is structured according to ethical rules, the outcome should be ethical—although not usually one that fits the value system of any competing party perfectly. (Grunig \& Grunig, 1992, p. 308)

The fact that the institution most often sets the "rules," however, raises concerns regarding the ethics of a process in which the power to establish the operating principles lies in the hands of one party.

In addition, this model might be criticized for going too far in requiring practitioners to meet the needs of constituents. As institutional advocates, public relations professionals represent a particular point of view that may or may not be harmful to those influenced by it. Is the responsibility to ensure that mutual benefit is gained or is it, rather, to ensure that no harm results from an anticipated decision or action?

In other words, just how far should public relations professionals should go in counseling their clients and employers to address the needs of constituents? As Grunig and Grunig (1992) themselves observed, "Practitioners of the two-way symmetrical model are not completely altruistic; they also want to defend the interests of their employers-they have mixed motives" (p. 320).

In summary, these previously proposed theories of public relations ethics make significant contributions to our understanding of the ethical challenges encountered in the practice of public relations. Yet, for various reasons, each falls short of providing a universally acceptable philosophy on which standards of ethical public relations practice might be based.

\section{Toward a Professional Responsibility Theory of Public Relations Ethics}

"Central to the importance of ethics in American public relations is the reality that, most of the time, practitioners have the voluntary choice of whether to be ethical or not" (Wright, 1989, p. 3). This statement by public relations scholar Don Wright captures the need for the development of a philosophical foundation for ethical decision making in public relations. Practitioners need some basis on which to judge the rightness of the decisions they make everyday. They need ethical principles derived from the fundamental values that define their work as public relations professionals. They need guidance in reconciling the potentially conflicting roles of the professional advocate and the social conscience. 
An important first step in developing such standards is recognition of the public relations practitioner's position as a professional. Notwithstanding the debate about whether the field's members have achieved professional status, we presume such standing. Thus, the special ethical obligations of a professional must be addressed. As Goldman (1992) observed, "[Professionals must be committed to] some overriding value that defines both expertise and service, whether it be health, salvation, the protection of legal rights, or the provision of public information, knowledge, and education" (p. 1019).

In reviewing the professions literature, four criteria emerge as the defining characteristics of a professional: membership in an occupational organization, special expertise, a service orientation, and autonomy. In writing about the professions in 1960, W. J. Goode stated what is still true today

If one extracts from the most commonly cited definitions all the items which characterize a profession ... a commendable unanimity is disclosed, ... core characteristics are a prolonged specialized training in a body of abstract knowledge, and a collectivity or service orientation. (p. 671)

\section{Another states}

[A] professional service requires, among other things, advanced intellectual training, mastery of technical subject matter, the exercise of skilled and responsible judgment. These attributes are beyond appraisal by the client ... the client must take the professional man [sic] on faith-faith in his competence and faith in his motives. (Carey, 1957, p. 7)

Put another way, "Professionals are charged by their clients with making important decisions on their behalf, and they are compensated for assuming this decision making responsibility and bringing their knowledge to bear on the decisions" (Wolfson, Trebilcock, \& Tuohy, 1980, p. 191). "A qualified professional is supposed to be an authority on his subject as a body of knowledge and an expert on the application to the solution of particular problems presented by clients" (Moore, 1970, p. 106).

Professionalism involves the application of a general system of knowledge to the circumstances of a particular case. In treating a client's problem, this knowledge is necessary (1) to identify the precise nature of the problem (diagnosis), (2) to determine the best way of dealing with it (prescription), and (3) to provide specialized services so as to solve the problems (therapy). (Wolfson et al., 1980, p. 190-191)

The professional services provided by public relations professionals include expert counsel on matters involving institutional relationships with constituents and the management of communication between the two. 
Special knowledge regarding the formation of public opinion, social science research, media channels, and communication strategies and tactics is assumed.

In rendering these special services, "the professional proceeds by his own judgment and authority; he thus enjoys autonomy restrained by responsibility" (Moore, 1970, p. 6). Public relations professionals—as professionals-have obligations that extend beyond the profitability (however defined) of the organization represented. Responsibility to the public-or in the case of public relations, to multiple publics-must be balanced with responsibility to a client or employer.

Indeed, public service always has been the hallmark of the professions, which serve society by providing essential services. Carey (1957) concluded that professionals enjoy the prestige of professional status because "they are presumed to accept a special obligation to place service ahead of personal gain" (p. 7). In a recent study, Reynolds (2000) observed that "society grants professional standing to those groups which contribute to the well-being of the broader society" (p. 115).

To summarize, professionals perform an essential public service that is realized through the provision of specialized services to clients or employers who retain them because of their special expertise and trust them to represent their interests. Because of this special relationship, the professional owes the client his or her loyalty. In fact, some would go so far as to define such associations as "fiduciary" relationships to which legal liabilities attach (see Black's Law Dictionary, 1979, defining a "fiduciary" relationship as one in which there exists a "reposing of faith, confidence, and trust, and the placing of reliance by one upon thejudgment and advice of another," p.6).

Thus, as professionals, it would seem that public relations practitioners owe a higher duty to client organizations and employers than to these institutions' constituents. This would support the role of public relations professionals as advocates of-and voices for-institutional interests. By definition, an advocate is one who pleads another's cause or who speaks or writes in support of something" (Webster's New World Dictionary, 1979, p. 20).

Now, how does this jibe with the oft assumed function of the public relations practitioner as the institutional social conscience? The term suggests that one who serves in such a capacity counsels an institution regarding the social implications of decisions and actions and-as a "conscience"advises the institution to take actions that are in the best interest of society and to avoid those that are not. The concept seems simple in language and, on its face, seems to be in line with the professional's obligation to serve the public interest. However, the vagueness of such responsibility may be the reason public relations professionals struggle with this concept.

How does an institution best serve society? This is the question that public relations professionals must resolve if they truly are to serve as the 
social consciences of the organizations they represent. It's a big question and, indeed, one that business leaders throughout the world have not been able to answer. Following a 10-year study in the corporate arena on issues related to corporate social responsibility, Clarkson (1995) concluded that there is "[no] general agreement about the meaning of these terms from an operational or a managerial viewpoint" (p. 92).

Scholars in public relations have reached the same conclusion. The question, as posed by public relations scholar Tom Bivins (1993), is "How can a practitioner advocating a discrete point of view serve the interest of the greater public" (p. 120)?

Bivins (1993) suggested four possible paradigms:

First, if every individual practicing public relations acts in the best interest of his or her client, then the public interest will be served.

Second, if, in addition to serving individual interests, an individual practicing public relations serves public interest causes, the public interest will be served.

Third, if a professional or professionals assure that every individual in need of or desiring its/their services receives its/their services, then the public interest will be served.

Fourth, if public relations as a profession improves the quality of debate over issues important to the public, then the public interest will be served. (p. 120)

Noting that none of three approaches provides the definitive answer, Bivens (1993) concluded that

In its dual role as mediator and advocate, public relations has the opportunity both to engage in and to encourage public debate. By doing so, it also has the opportunity, and the obligation, to lessen the obfuscation often surrounding the mere provision of information. It must develop clear guidelines and formal mechanisms by which issues important to society are clarified and presented to the public for open, democratic debate. (p. 121)

Bivins's (1993) focus on the value of ethical communication to open public debate captures the essence of public relations' social role. By providing voices for special interests, public relations contributes to the harmonization of diverse points of view, thereby promoting "mutual understanding and peaceful coexistence among individuals and institutions" (Seib \& Fitzpatrick, 1995, p. 1).

To get beyond the general concepts of social responsibility or public service, however, we must focus on public relations practitioners as professionals rather than as communicators. Although, as noted earlier, we reject the idea that the attorney-adversary model is fully appropriate as a moral 
foundation for public relations, the professional service model employed in the legal profession may be an appropriate guide for determining the ethical — and morally justifiable — role of the public relations professional.

Lawyer jokes aside, people in and outside the legal profession recognize the value of the legal profession in the functioning of a democratic society. Attorneys represent clients to ensure that they are treated fairly in the criminal and civil justice systems, to ensure that their legal interests are protected. Lawyers serve as zealous advocates of their clients, with no special obligation to the opposing party. In other words, they serve the public's interest by serving their clients' interests. A former federal judge put it this way:

To the client [the lawyer] owes loyalty, undivided and undiluted, zeal and devotion and some additional obligations.... His object is to achieve for his client the best which is available within the law by means compatible with the canons of ethics. (As cited in Gillers \& Dorsen, 1989, p. 22)

The judge went on to say that the lawyer also owes duties to the profession and to the community. "From the community, the lawyer derives his special status, special franchise, his unique accessory role" (Gillers \& Dorsen, 1989, p. 22).

In applying this analogy to public relations, it can be argued that public relations professionals best serve society by serving the special interests of their clients and employers. Like other professionals, however, they must balance such service with their obligations to operate in the public interest. In public relations this means that the special interests of the institution served must be balanced with the interests of those directly affected by the institution.

Such balancing begins with the recognition that the public relations professional's greatest loyalty is to his or her client. At the same time, he or she ensures that the institution hears and considers the interests of its stakeholders. We contend that serving the public interest simply requires public relations professionals to consider the interests of all affected parties and make a committed effort to balance them to the extent possible while avoiding or minimizing harm and respecting all of the persons involved.

As such, a significant aspect of professional responsibility means responsibility to publics. In this way, we borrow from the meaning of public interest in the public policy arena:

[P]ublic interest is part of our political language-a term we use to express concern for all interests affected by a decision and for a set of fundamental social principles. Invoking the public interest requires all parties to a discussion to make their arguments in terms of these interests and these principles, and it 
requires that the consequences of all proposals be shown and discussed in a public forum. (Wolfson et al., 1980, p. 84)

Thus, the views of those affected by an institution's decisions and actions should be heard before decisions are made or action is taken.

In further developing this idea, we propose that the term social conscience be eliminated from the public relations literature. Such terminology simply contributes to the confusion about the proper role of public relations. In addition to the fact the term appears to be indefinable, many contemporary practitioners reject the title as an accurate reflection of their work (see, e.g., Katzman, 1993). Additionally, there is some evidence that public relations is not viewed by institutional leaders as the appropriate function to serve in the capacity of a social conscience. Many organizations that have taken steps to institutionalize ethics have turned to legal or other advisors outside public relations for advice in this area (see, e.g., Fitzpatrick, 1996). At the same time, only a third of corporate Chief Executive Officers participating in a recent survey said they sought the counsel of public relations advisors on matters related to social responsibility (Fitzpatrick, 2000).

Next, we propose that the term social conscience be replaced with the term public conscience. Although the terms social or society are acceptable in reference to the groups of people affected by institutional decisions and actions, they carry a sense of the "greater society" rather than of those specifically and directly affected by or, alternately, who affect an institution in a given situation.

In the context of public relations, the term public is widely defined as "a specific part of the people; those people considered together because of some common interest or purpose" (Webster's New World Dictionary, 1979, p. 1148). Thus, the use of the term public conscience better captures the more focused obligation of public relations professionals to best serve society by balancing their clients' and employers' interests with the interests of those directly associated with their clients' decisions and actions.

A social conscience provides moral limits or checks on decision-making power within an institution that has effects (good and ill) on society, both individual members and the society as a whole. A public conscience weighs the effects of decisions and actions on specific parties, thereby serving society by serving these special interests.

A theory of public relations ethics based on responsibility to specific publics not only helps to resolve the ambiguity of such phrases as "serve the public interest" and "social responsibility." It also reflects what recent studies in the field have concluded-that "relationships ought to be at the core of public relations scholarship and practice" (Ledingham \& 
Bruning, 2000, p. xiii). By focusing on relationships between an organization and its constituents-rather than on an organization's relationship with or obligation to serve an intangible society-scholars and public relations professionals can begin to define an organization's ethical responsibilities to its publics. Then practitioners can go further in defining standards of performance that are appropriate to the ethical practice of public relations.

\section{Principles of Responsible Advocacy in Public Relations}

For the public relations practitioner, as for most professionals, moral dilemmas arise when loyalties and responsibilities conflict and a course of action must be chosen. A moral dilemma occurs when a choice is required among actions that meet competing commitments or obligations, but there are good reasons for and against each alternative.

For other professionals, such as health care providers, ethical principles have proven useful in identifying the conflicting responsibilities in a moral dilemma, bringing clarity to moral thinking and providing a shared language for discussion.

Three principles that could provide the foundation for a theory of professional responsibility in public relations are

1. The comparison of harms and benefits: Harms should be avoided or, at least, minimized, and benefits promoted at the least possible cost in terms of harms.

2. Respect for Persons: Persons should be treated with respect and dignity.

3. Distributive Justice: The benefits and burdens of any action or policy should be distributed as fairly as possible. ${ }^{1}$

\section{Principles hold generally unless they conflict.}

It is important to recognize that these are prima facie, and not absolute, principles. ${ }^{2}$ They are principles that hold generally unless they conflict with one another. When only one of the principles is implicated in a moral choice, that principle should be taken as the controlling guideline for ethical conduct. However, moral dilemmas often involve conflicts between the principles. In these cases, the decision maker must employ his or her own values, moral intuition, and character to determine which 
principle is most important and most controlling in the particular context.

As Aristotle (1975) pointed out, determining the morally right action is difficult based on reasoning alone, as with the application of ethical theories and principles. We must learn to discern the morally relevant particulars in each situation and ultimately, "the decision rests with perception" (Aristotle, 1975, Book II, Section 9, p. 47).

Moreover, the use of ethical principles in approaching moral choice and action does not ignore the importance of virtues or the character of the decision maker. Aristotle (1975) argued that a good character is the product of habit. One becomes virtuous by practicing virtuous actions over a lifetime (Book II, Section 1, pp. 28-29; Section 4, pp. 34-35). Ethical principles can guide us in the recognition of the morally right or virtuous act and, acting accordingly, over time we can develop both the moral discernment and the habits of morally right action that comprise a good character.

Application of the first principle requires the identification and comparison of harms and benefits expected to result from a proposed course of action or policy. ${ }^{3}$ All of the affected parties and interests must be considered and weighed impartially (Mill, 1861/1979, pp. 16-17). The probability and seriousness of the possible harms must be determined, as must the probability and extent of the expected benefits. According to this principle, causing harm is worse than not providing a benefit. In a true moral dilemma some harm or risk of harm is often anticipated, so that when harm cannot be avoided, it should at least be minimized to the extent possible. Because this principle requires a comparison of harms and benefits, its application will rely on the perception of particulars and the values of the decision maker.

Respect for persons requires that persons be treated with respect and dignity, so that their decision-making abilities, choices, and actions are supported rather than interfered with, to the extent consistent with equal respect for others. ${ }^{4}$ This principle prohibits deception, manipulation, and coercion, as these forms of influence interfere with the decision-making process.

The principle of justice is based on the value of fairness. It requires that benefits and burdens, in terms of risk of harm and actual harm, be distributed among the affected parties as fairly as possible. This principle is particularly useful as a supplement to the first two principles.

These three principles often work in combination, supporting and supplementing each other to provide more concrete guidance in moral decision making. For example, fairness requires that benefits for one group or interest should not be secured at the cost of disproportionate harms to another group without adequate justification, and everyone affected should be treated with respect and dignity. Similarly, when harm is unavoidable, it should be minimized to the extent possible, and those 
harmed deserve an explanation out of respect for their value as persons. They may also deserve compensation based on the principle of justice.

Once actions are taken and their effects are known, the professional responsibility theory further requires that those whose decisions resulted in these actions and effects must fully accept and admit responsibility for them. Here, the communication specialist role for public relations becomes particularly important. When organizational actions or policies turn out badly and when harm is done, the public relations professional will shoulder the task of explaining and perhaps attempting to justify those actions or policies to those who have been adversely affected, as well as to the wider public.

Whether the public relations communicator is announcing actions or policies at their inception or explaining and justifying them when something goes wrong, respect for persons and the avoidance of further harm will be particularly relevant. Although respect for persons requires honesty, this does not mean that selective communication and persuasion are automatically ruled out. They do, however, require some limits and careful consideration of their purposes and how they are meant to influence target audiences.

Selective communication is morally suspect when it is intended to mislead or when it is used to conceal information that others need to make their own life decisions. Yet, not everything that is known, believed, or communicated within an organization needs to be made public.

Questions that may assist in a moral evaluation of selective communication in a particular case include the following: For what purpose is selectivity in communication being employed here? What was not selected for release and why not? Is the selective release of information meant to mislead or deceive the target audience? Is the information held back needed by the audience for their own choices and actions? Will not having this information risk or cause harm to any person, group, or interest?

Persuasion need not be deceptive or harmfully manipulative to be effective. It is possible to use persuasive communication to appeal to the rational faculties of a target audience, to affect attitudes and beliefs through honest conviction, and to point out good reasons for specific choices and actions. Rational persuasion respects persons when it contributes truthful, relevant information in the form of facts and reasons to the decision-making process. This is quite different than deception or manipulation that operate by interfering with that process.

Questions that may assist in a moral evaluation of a specific use of persuasion include the following: For what purpose is persuasion being employed here? Toward what choices and with what consequences for individual lives is persuasion being used? Does the persuasion in this case contribute to or interfere with the decision-making process for its target audience? 


\section{Conclusions}

A professional responsibility theory of public relations has advantages over other theories in part because it attempts to reconcile the dual roles of the public relations professional as institutional advocate and public conscience for that institution. The inclusion of responsibilities to the various publics affected by institutional actions and policies, in addition to the institution itself, broadens the more narrow focus on institutional interests found in both the attorney-adversary and enlightened self-interest models. Conversely, the emphasis on public rather than social responsibility narrows the overwhelming and unrealistic focus of a communitarian model on the community or society as a whole.

The ethical principles that form the philosophical foundation for the professional responsibility theory also may provide more concrete guidance than do other approaches in resolving ethical dilemmas caused by conflicting obligations to a variety of competing interests. These principles also suggest a series of questions that may assist the public relations practitioner in serving both as institutional advocate and public conscience in a morally responsible way.

The next step in developing a professional responsibility theory of public relations will be to apply these principles and questions to real moral dilemmas and ethical issues that arise in public relations practice. As many who work in other disciplines have realized, the interaction between principles and cases in practical application is indispensable for both the development of practical judgment and the grounding and refinement of ethical theory (Jonsen, 1991).

\section{Notes}

1. Tom Beauchamp and James Childress (1994) are responsible for developing the four basic principles of health care ethics: Respect for Autonomy, Beneficence, Non-Maleficence, and Justice. The three principles discussed here are modifications of their model developed specifically for public relations ethics. See also Lisa H. Newton $(1989$, p. 21). This study guide was prepared for the Ethics in America television series, produced by Columbia University Seminars on Media and Society. The ethical principles, "Do Good, or at Least Do No Harm, Observe the Requirements of Justice, and Respect Persons" were meant to guide professional conduct in politics, medicine, business, journalism, the military, and the law. For business ethics specifically, see Richard T. De George (1995, pp. 60-109) and Thomas Donaldson and Patricia H. Werhane (1996, pp. 1-12). In both texts, ethical analysis is based on (a) utilitarian or consequential theory in which benefits and harms are compared, (b) deontological or Kantian theory in which respect for persons is paramount, and (c) considerations of justice. 
2. This conception of the principles as prima facie is borrowed from the prima facie duties of W. D. Ross (1930).

3. This principle is a combination of Non-Maleficence and Beneficence in Beauchamp and Childress (1994). It originates in Mill (1861/1979).

4. This principle is similar to Respect for Autonomy in Beauchamp and Childress (1994). The change to "persons" and the emphasis on respect and dignity refer back to its original source in Immanuel Kant (1785/1959, pp. 46-47).

\section{References}

Aristotle. (1975). Nicomachean ethics (Sir David Ross, Trans.). London: Oxford University Press.

Baker, S. (1999). Five baselines for justification in persuasion. Journal of Mass Media Ethics, 14, 69-81.

Barney, R., \& Black, J. (1994). Ethics and professional persuasive communications. Public Relations Review, 20(3), 233-248.

Beauchamp, T., \& Childress, J. (1994). Principles of biomedical ethics. New York: Oxford University Press.

Black's Law Dictionary (5th ed.). (1979). St. Paul, MN: West.

Bivins, T. H. (1989). Are public relations texts covering ethics adequately? Journal of Mass Media Ethics, 4, 39-52.

Bivins, T. H. (1993). Public relations, professionalism, and the public interest. Journal of Business Ethics, 12, 120-121.

Carey, J. L. (1957, March). Professional ethics are a helpful tool. Public Relations Journal.

Clarkson, M. B. E. (1995). A stakeholder framework for analyzing and evaluating corporate social performance. Academy of Management Review, 20, 92-117.

De George, R. (1995). Business ethics (4th ed.). Englewood Cliffs, NJ: Prentice Hall.

Donaldson, T., \& Werhane, P. (1996). Ethical issues in business (5th ed.). Upper Saddle River, NJ: Prentice Hall.

Fitzpatrick, K. R. (1996). The role of public relations in the institutionalization of ethics. Public Relations Review, 22(3), 249-258.

Fitzpatrick, K. R. (2000). CEO views on corporate social responsibility. Corporate Reputation Review, 3, 290-300.

Gillers, S., \& Dorsen, N. (1989). Regulation of lawyers: Problems of law and ethics (2nd ed.). Boston: Little, Brown.

Goldman, A. H. (1992). Professional ethics. In C. Becker \& C. B. Becker (Eds.), Encyclopedia of Ethics (Vol. 2), pp. 1018-1020. New York: Garland.

Grunig, J. E. (Ed.). (1992). Excellence in public relations and communication management. Hillsdale, NJ: Lawrence Erlbaum Associates, Inc.

Grunig, J. E., \& Grunig, L. A. (1992). Models of public relations and communications. In J. Grunig (Ed.), Excellence in public relations and communication management. Hillsdale, NJ: Lawrence Erlbaum Associates, Inc.

Grunig, J. E., \& Grunig, L. A. (1996, May). Implications of symmetry for a theory of ethics and social responsibility in public relations. Paper presented to the Public Relations Interest Group, International Communication Association, Chicago, IL. 
Jonsen, A. (1991). Of balloons and bicycles or the relationship between ethical theory and practical judgment. The Hastings Center Report, 21(5), 14-16.

Kant, I. (1959). Foundations of the metaphysics of morals (L. W. Beck, Trans.). New York: Bobbs-Merrill. (Original work published 1785)

Katzman, J. B. (1993). What's the role of public relations? Profession searches for its identity. Public Relations Journal, 49(4), 11-17.

Kruckeberg, D., \& Starck, K. (1988). Public relations and community: a reconstructed theory. New York: Praeger.

Ledingham, J., \& Bruning, S. D. J. (2000). Introduction: Background and current trends in the study of relationship management. In J. Ledingham \& S. D. F. Bruning (Eds.), Public relations as relationship management: A relationship approach to the study and practice of public relations (p. xiii). Mahwah, NJ: Lawrence Erlbaum Associates, Inc.

Leeper, K. A. (1996). Public relations ethics and communitarianism: A preliminary investigation. Public Relations Review, 22(2), 163-179.

L'Etang, J. (1994). Public relations and corporate responsibility: Some issues arising. Journal of Business Ethics, 13, 111-123.

Martinson, D. (1994). Enlightened self-interest fails as an ethical baseline in public relations. Journal of Mass Media Ethics, 9, 100-108.

Mill, J. S. (1979). Utilitarianism. Indianapolis, IN: Hackett. (Original work published 1861)

Moore, W. (1970). The professions: Roles and rules. New York: Russell Sage Foundation.

Murphy, P. (1991). The limits of symmetry: A game to symmetric and asymmetric public relations. Public Relations Research Annual, 3, 115-132.

Newton, L. (1989). Ethics in America study guide. Englewood Cliffs, NJ: Prentice Hall.

Pearson, R. (1989). Reviewing Albert J. Sullivan's theory of public relations ethics. Public Relations Review, 15(2), 52-62.

Public Relations Society of America (1991). Public relations: An overview. PRSA Foundation Monograph Series, 1(3).

Reynolds, M. A. (2000). Professionalism, ethical codes and the internal auditor: A moral argument. Journal of Business Ethics, 24, 115-124.

Ross, W. D. (1930). The right and the good. London: Oxford University Press.

Seib, P., \& Fitzpatrick, K. (1995). Public relations ethics. Fort Worth, TX: Harcourt Brace.

Sullivan, A. J. (1965). Values in public relations. In O. Lerbinger \& A. Sullivan (Eds.), Information, influence, and communication: A reader in public relations. (pp. 412-439) New York: Basic Books.

Webster's New World Dictionary, Second College Ed. (1979). New York: William Collins.

Whalen, P. (1998, August). Enlightened self-interest: An ethical baseline for teaching corporate public relations. Paper presented to the Public Relations Division, Association for Education in Journalism and Mass Communication.

Wolfson, A. D., Trebilcock, M. J., \& Tuohy, C. J. (1980). Regulation of the professions: A theoretical framework. In S. Rotenberg (Ed.), Occupational licensure and regulation (pp. 180-214). Washington, DC: American Enterprise for Public Policy Research. Wright, D. K. (1989). Ethics research in public relations. Public Relations Review, 15(2), 3-5. 